\title{
Kandungan Nitrat dan Fosfat Sedimen serta Keterkaitannya dengan Kerapatan Mangrove di Kawasan Mertasari di Aliran Sungai TPA Suwung Denpasar, BALI
}

\author{
Ni Nyoman Desi Kusuma Dewi *,I Gusti Ngurah Putra Dirgayusa , Yulianto Suteja \\ ${ }^{a}$ Faculty of Marine Science and Fisheries, Udayana University, Bukit Jimbaran, Bali 80361, Indonesia \\ *Penulis koresponden. Tel.: +6281-338-819-142 \\ Alamat e-mail: mangdesi60@gmail.com
}

Diterima (received) 5 Januari 2017; disetujui (accepted) 18 Juni 2017; tersedia secara online (available online) 20 Juni 2017

\begin{abstract}
Mangrove is a green plants tolerant of salt water, which grows mainly along the sheltered coastal areas, especially along the bay or in estuaries. Final Disposal (TPA) Rubbish Suwung which located in the village Pedungan South Denpasar District is the rubbish dumps originating from the city of Denpasar and Badung. There is a natural mangrove vegetation in the river TPA. Mertsari area which located in the village of Sanur, West Denpasar District is a mangrove planting area and tourism destination on the Mertasari Beach. The purpose of this research are as follows: (1) To identify the content of nitrate and phosphate in mangrove sediments, (2) To determine the density of mangrove in Region Mertasari and TPA Suwung River Flow and (3) To describe the mangrove density is linkage with nitrate and phosphate mangrove sediments. The method used on this research is linear regression. Nitrate and phosphate sediments of mangroves in TPA Suwung River Flow and Region Mertasari range of 0.04 ppm - 79.034 ppm. The average density results of the mangrove tree level, saplings and seedlings in different locations ranged 0.01 ind $/ \mathrm{m}^{2}$ 0.32 ind $/ \mathrm{m}^{2}$. The river's flow TPA Suwung produce a simple linear regression calculation of nitrate mangrove sediments density $y=-0,002 x+0,288\left(R^{2}\right) 10,1 \%$, and the calculation of the density sedimentary phosphate mangrove produce $y=0,007 x+0,125\left(R^{2}\right) 6,1 \%$. The results of simple linear regression calculation of nitrate sediments density Mertasari mangrove area is $y=-0,002 x+0,537 R^{2}=4,7 \%$, and the calculation of the density sedimentary phosphate mangrove produce $y=-0,038 x+0,777\left(R^{2}\right) 63,7 \%$.
\end{abstract}

Keywords: mangrove; density; nitrate; phosphate; sedimen

\begin{abstract}
Abstrak
Mangrove merupakan tumbuhan hijau yang toleran terhadap air asin yang tumbuh terutama sepanjang daerah pantai terlindung, khususnya sepanjang teluk atau di dalam estuaria. Tempat Pembuangan Akhir (TPA) Sampah Suwung terletak di Desa Pedungan Kecamatan Denpasar Selatan merupakan tempat pembuangan akhir sampah yang berasal dari Kota Denpasar dan Kabupaten Badung terdapat tumbuhan mangrove alami di aliran sungai TPA. Di Kawasan Mertasari terletak di Desa Sanur Kauh Kecamatan Denpasar merupakan tempat penanam mangrove dan sebagai obyek wisata di pantai mertasari. Tujuan dari penelitian ini, yaitu : (1) Mengetahui kandungan nitrat dan fosfat pada sedimen mangrove, (2) Mengetahui kerapatan mangrove di Kawasan Mertasari dan Aliran Sungai TPA Suwung dan (3) Mengetahui keterkaitan kerapatan mangrove dengan kandungan nitrat dan fosfat sedimen mangrove. Metode yang digunakan dari penelitian ini adalah regresi linier. Kandungan nitrat dan fosfat sedimen mangrove di Aliran Sungai TPA Suwung dan Kawasan Mertasari berkisar 0,04 ppm - 79,034 ppm. Rata - rata hasil kerapatan jenis mangrove tingkat pohon, anakan dan semai di lokasi yang berbeda berkisar $0,01 \mathrm{ind} / \mathrm{m}^{2}-0,32 \mathrm{ind} / \mathrm{m}^{2}$. Aliran sungai TPA Suwung menghasilkan perhitungan regresi linier sederhana nitrat sedimen dengan kerapatan mangrove $y=-0,002 x+0,288\left(R^{2}\right) 10,1 \%$, dan perhitungan fosfat sedimen dengan kerapatan mangrove menghasilkan $y=0,007 x+0,125\left(R^{2}\right) 6,1 \%$ Hasil perhitungan regresi linier sederhana nitrat sedimen dengan kerapatan mangrove dikawasan Mertasari yaitu $y=-0,002 x+0,537 R^{2}=4,7 \%$, dan perhitungan fosfat sedimen dengan kerapatan mangrove menghasilkan y $=-0,038 x+0,777\left(R^{2}\right) 63,7 \%$.
\end{abstract}

Kata Kunci: mangrove; kerapatan; nitrat; fosfat; sedimen 


\section{Pendahuluan}

Hutan mangrove adalah komunitas vegetasi pantai tropis dan merupakan komunitas yang hidup di dalam kawasan yang lembab dan berlumpur serta dipengaruhi oleh pasang surut air laut (Feller et al., 2010; Mahasani et al., 2015). Mangrove merupakan tumbuhan hijau yang toleran terhadap air asin yang tumbuh terutama sepanjang daerah pantai terlindung, khususnya sepanjang teluk atau di dalam estuaria (Polidoro et al., 2010). Mangrove dapat tumbuh dan berkembang secara maksimum dalam kondisi penggenangan dan pergantian sedimen secara terus menerus. Sirkulasi yang terus menerus dapat meningkatkan pasokan oksigen dan nutrien, untuk keperluan fotosintesis dan respirasi (Dahuri et al., 2008).

Ekosistem mangrove merupakan ekosistem utama peyusun ekosistem wilayah pesisir berupa formasi tumbuhan litoral dengan karakteristik terdapat didaerah tropika dan sub tropika, terhampar disepanjang pesisir. Wilayah pesisir merupakan ekosistem yang paling mudah terkena dampak kegitan manusia dalam pembangunan baik secara langsung maupun tidak langsung berdampak pada penurunan kualitas lingkungan (Pratiwi dan Ernawati, 2016; Lewis et al., 2011).

Penurunan kualitas lingkungan mangrove akan berpengaruh terhadap distribusi kandungan nitrat dan fosfat didalam sedimen yang akan mempengaruhi kesuburan mangrove. Sumber sedimen dikawasan mangrove berasal dari daratan dan lautan serta dari mangrove itu sendiri berupa guguran daun, ranting, dan organisme mati yang terdeposisi di daerah mangrove (Budiasih et al., 2015).

Pantai Mertasari dan Aliran Sungai Di TPA Suwung yang berada di Provinsi Bali, tepatnya di daerah pusat kota Denpasar. Kedua tempat ini memiliki karakteristik yang berbeda yaitu dikawasan mertasari merupakan kawasan mangrove alami yang berhadapan langsung dengan laut lepas, Aliran Sungai TPA Suwung merupakan kawasan yang dipengaruhi oleh aktivitas manusia yang dekat dengan tempat pembuangan akhir kota Denpasar. Menurut Arbain et al (2008), tingginya kosentrasi nitrat dan fosfat pada air tanah dangkal yang bersumber dari cairan limbah TPA Sampah Suwung, pertanian, pengolahan ikan serta kegiatan masyarakat.
Melihat pentingnya pertumbuhan mangrove bagi kesuburan mangrove di Pantai Mertasari dan Aliran Sungai TPA Suwung, maka penting dilakukan pengujian kandungan nitrat fosfat dalam sedimen mangrove yang ada keterkaitannya dengan kerapatan mangrove.

\section{Metode Penelitian}

\subsection{Waktu dan Lokasi Penelitian}

Penelitian ini dilaksanakan pada bulan Mei 2016 sampai bulan Juni 2016. Penelitian ini meliputi pengambilan data kerapatan mangrove dan sedimen mangrove yang kemudian dilakukan pengujian kandungan nitrat dan fosfat sedimen di Laboratorium Analitik Universitas Udayana. Penelitian ini dilakukan di Kawasan Mertasari dan Aliran Sungai TPA Suwung.

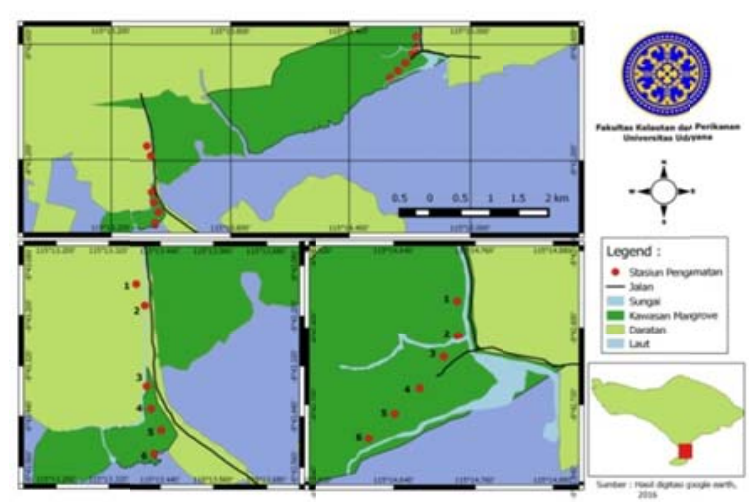

Gambar 1. Peta Lokasi Penelitian

\subsection{Alat dan Bahan}

Adapun alat yang akan digunakan dalam penelitian ini dapat dilihat pada Tabel 1. Adapun bahan yang akan digunakan pada penelitian ini dapat dilihat pada Tabel 2.

\subsection{Metode Pengumpulan Data}

\subsubsection{Pengambilan Sampel Sedimen}

Pengambilan sampel sedimen dilakukan di 12 (dua belas) titik yang diambil secara acak menggunakan pipa paralon dengan diameter 10 $\mathrm{cm}$ sepanjang $30 \mathrm{~cm}$ kedalaman $20 \mathrm{~cm}$ pada masing - masing stasiunnya sebanyak $100 \mathrm{~g}$ dengan keseluruhan sampel 12 sampel sedimen yang kemudian di analisis di laboratorium analitik universitas udayana. 
Tabel 1

Alat yang digunakan dalam penelitian

\begin{tabular}{|c|c|c|c|}
\hline No & Alat & Spesifikasi & Kegunaan \\
\hline 1 & Kertas Label & - & $\begin{array}{l}\text { Memberikan label } \\
\text { pada sampel }\end{array}$ \\
\hline 2 & $\begin{array}{l}\text { Alat tulis } \\
\text { menulis }\end{array}$ & - & $\begin{array}{l}\text { Mencatat hasil } \\
\text { pengamatan }\end{array}$ \\
\hline 3 & Roll Meter & $100 \mathrm{~m}$ & $\begin{array}{l}\text { Mengukur antar } \\
\text { stasiun }\end{array}$ \\
\hline 4 & Patok & - & $\begin{array}{l}\text { Membatasi antar } \\
\text { stasiun }\end{array}$ \\
\hline 5 & $\begin{array}{l}\text { Buku } \\
\text { Identifikasi } \\
\text { Mangrove }\end{array}$ & $\begin{array}{l}\text { Buku Panduan } \\
\text { Mangrove } \\
\text { Indonesia Oleh } \\
\text { Shozo } \\
\text { Kitamura }\end{array}$ & $\begin{array}{l}\text { Mengetahui jenis } \\
\text { mangrove yang } \\
\text { didapatkan }\end{array}$ \\
\hline 6 & GPS & GPS MAP $78 \mathrm{~S}$ & Menentukan stasiun \\
\hline 7 & $\begin{array}{l}\text { Kantong } \\
\text { Plastik }\end{array}$ & - & $\begin{array}{l}\text { Menyimpan sampel } \\
\text { sedimen }\end{array}$ \\
\hline 8 & Pipa Paralon & - & $\begin{array}{l}\text { Mengambil Sampel } \\
\text { Sedimen }\end{array}$ \\
\hline 9 & $\begin{array}{l}\text { Spektrofoto- } \\
\text { meter }\end{array}$ & $400-700 \mathrm{~nm}$ & $\begin{array}{l}\text { Mengukur } \\
\text { absorbansi }\end{array}$ \\
\hline 10 & Erlenmeyer & $50 \mathrm{ml}, 100 \mathrm{ml}$ & $\begin{array}{l}\text { Menyimpan dan } \\
\text { memanaskan larutan }\end{array}$ \\
\hline 11 & Labu Ukur & $\begin{array}{l}10 \mathrm{ml}, 100 \mathrm{ml}, \\
250 \mathrm{ml}\end{array}$ & $\begin{array}{l}\text { Menampung dan } \\
\text { mencampurkan } \\
\text { larutan kimia }\end{array}$ \\
\hline 12 & Gelas Ukur & $\begin{array}{l}5 \mathrm{ml}, 10 \mathrm{ml}, 100 \\
\mathrm{ml}\end{array}$ & $\begin{array}{l}\text { Mengukur volume } \\
\text { larutan }\end{array}$ \\
\hline 13 & Pipet Ukur & - & $\begin{array}{l}\text { Mengambil larutan } \\
\text { dengan volume } \\
\text { tertentu }\end{array}$ \\
\hline 14 & $\begin{array}{l}\text { Pipet } \\
\text { volumetrik }\end{array}$ & - & $\begin{array}{l}\text { Mengambil larutan } \\
\text { dengan volume tepat } \\
\text { Memindahkan }\end{array}$ \\
\hline 15 & Pipet Tetes & - & $\begin{array}{l}\text { beberapa tetes zat } \\
\text { cair }\end{array}$ \\
\hline 16 & $\begin{array}{l}\text { Timbnagan } \\
\text { Elektronik }\end{array}$ & $\begin{array}{l}\text { Merek : } \\
\text { SHIMADZU } \\
\text { Type : ELB-300 } \\
\end{array}$ & Menimbang sampel \\
\hline
\end{tabular}

Tabel 2

Bahan yang digunakan dalam penelitian

\begin{tabular}{|c|c|c|}
\hline No & Bahan & Kegunaan \\
\hline 1 & Sampel Sedimen & $\begin{array}{l}\text { Menguji kandungan } \\
\text { nitrat dan fosfat }\end{array}$ \\
\hline 2 & $\begin{array}{l}\text { Larutan Asam Sulfat } \\
(\mathrm{H} 2 \mathrm{SO} 4) 5 \mathrm{~N}\end{array}$ & Menguji sintesis kimia \\
\hline 3 & $\begin{array}{l}\text { Larutan Kalium Antimonil } \\
\text { Tartrat } \\
(\mathrm{K}(\mathrm{SbO}) \mathrm{C} 4 \mathrm{H} 4 \mathrm{O} 61 / 2 \mathrm{H} 2 \mathrm{O})\end{array}$ & $\begin{array}{l}\text { Membuat larutan standar } \\
\text { fosfat }\end{array}$ \\
\hline 4 & $\begin{array}{l}\text { Larutan Asam Askorbat } \\
\text { C6H8O6 0,1 M }\end{array}$ & $\begin{array}{l}\text { Mengekstrasi larutan } \\
\text { fosfat }\end{array}$ \\
\hline 5 & $\begin{array}{l}\text { Larutan Induk Nitrat N- } \\
\text { NO3 }\end{array}$ & $\begin{array}{l}\text { Membuat larutan standar } \\
\text { nitrat }\end{array}$ \\
\hline 6 & Larutan Nitrat & $\begin{array}{l}\text { Mencari kandungan } \\
\text { nitrat }\end{array}$ \\
\hline 7 & Larutan HCL $1 \mathrm{~N}$ & $\begin{array}{l}\text { Mengekstrasi larutan } \\
\text { nitrat }\end{array}$ \\
\hline 8 & Larutan Nitrat Intermediet & $\begin{array}{l}\text { Mengekstrasi larutan } \\
\text { nitrat }\end{array}$ \\
\hline
\end{tabular}

\subsection{Metode Pengolahan Data}

\subsubsection{Pengukuran Mangrove}

Pada setiap stasiun pengamatan, tentukan petak petak pengamatan/plot berukuran $10 \mathrm{~m}$ x $10 \mathrm{~m}$ sebanyak minimal 3 plot. Untuk pohon ukuran transek nya adalah $10 \mathrm{~m}$ x $10 \mathrm{~m}$, untuk anakan ukuran transek nya adalah $5 \mathrm{~m} \times 5 \mathrm{~m}$, untuk semai ukuran transeknya adalah $2 \mathrm{~m} \times 2 \mathrm{~m}$.

\subsubsection{Teknik Pengukuran Nitrat}

Pengukuran nitrat diperlukan $100 \mathrm{~g}$ sampel sedimen yang kemudian di encerkan. Sebelum pengukuran nitrat dilakukan terlebih dahulu lakukan persiapan uji dengan cara saring contoh air dengan kertas saring milipore 0,45 $\mu \mathrm{m}$ jika contoh air diduga mengandung klorin, maka hilangkan dengan menambahkan 1 tetes larutan natrium arsenit. Setelah itu lakukan pengukuran sampel nitrat dengan cara siapkan pipet $50 \mathrm{~mL}$ sampel, saring bila diperlukan. Kemudian tambahkan $1 \mathrm{~mL}$ HCL $1 \mathrm{~N}$ dan kocok hingga homogen.

\subsubsection{Pengukuran Fosfat}

Pengukuran fosfat diperlukan $100 \mathrm{~g}$ sampel sedimen yang kemudian di encerkan. Sebelum pengukuran fosfat dilakukan terlebih dahulu melakukan persiapan pengujian yaitu dengan cara membuat larutan indik fosfat $500 \mathrm{mg} / \mathrm{l}$, larutan baku fosfat $10 \mathrm{mg} / \mathrm{l}$, larutan kerja fosfat dan pembuatan kurva kalibrasi.

Selanjutnya lakukan pengukuran sampel fosfat dengan cara siapkan pipet $50 \mathrm{ml}$ contoh uji secara duplo dan masukkan masing - masing ke dalam erlenmeyer, kemudian tambhakan 1 tetes indikator fenoftalin. Jika terbentuk warna merah muda, tambahkan tetes demi tetes $\mathrm{H}_{2} \mathrm{SO}_{4} 5 \mathrm{~N}$ sampai warnanya hilang. Setelah itu tambahkan $8 \mathrm{~mL}$ lartan campuran dan di homogenkan yang kemudian masukkan ke dalam kuvet pada alat spektrofotometer, baca dan catat serapannya pada panjang gelombang $880 \mathrm{~nm}$ dalam kisaran waktu antara 10 menit sampai 30 menit.

\subsection{Analisis Data}

\subsubsection{Mangrove}

Perhitungan kerapatan mangrove adalah sebagai berikut : 
a. Kerapatan Jenis

$D_{i}=\frac{n_{i}}{A}$

Keterangan :

$D_{i} \quad=$ kerapatan jenis (individu/ $/ \mathrm{m}^{2}$ )

$n_{i} \quad=$ jumlah total tegakan jenis ke-i (pohon, anakan, semai)

$A \quad=$ luas total area pengambilan contoh (luas total petak contoh/plot) $\left(\mathrm{m}^{2}\right)$

b. Kerapatan Relatif Jenis (RDi)

Kerapatan relatif jenis (RDi) (\%) adalah perbandingan antara jumlah tegakan jenis ke-i dan jumlah tegakan seluruh jenis $\sum n$.

$R D i=\left(\frac{n i}{\sum n}\right) \times 100 \%$

Keterangan :

$R D_{i} \quad=$ kerapatan relatif jenis (\%)

$n_{i} \quad=$ jumlah total tegakan jenis ke-i

$\sum n \quad=$ jumlah tegakan seluruh jenis

2.4.1 Analisis Keterkaitan Kerapatan Jenis Mangrove Dengan Kandungan Nitrat Dan Fosfat Di Sedimen

Analisis yang digunakan untuk mengetahui keterkaitan kerapatan mangrove dan kandungan nitrat fosfat sedimen dilakukan melalui analisis korelasi. Analisis korelasi dapat dilihat sebgai berikut :

$$
r=\frac{n \sum(X i Y i)-\left(\sum X i\right)\left(\sum Y i\right)}{\sqrt{\left[n \sum X i^{2}-\left(\sum X i\right)^{2}\right]\left[n \sum Y i^{2}-\left(\sum Y i\right)^{2}\right]}}
$$

Keterangan :

$r \quad=$ Koefisien korelasi pearson

$n \quad=$ Banyaknya pasangan data $\mathrm{x}$ dan $\mathrm{y}$

$X$ = Kerapatan mangrove (tingkat pohon, anakan dan semai)

$Y \quad=$ Kandungan nitrat dan fosfat sedimen

$\sum X=$ Total jumlah dari variabel $\mathrm{x}$

$\sum Y=$ Total jumlah dari variabel $\mathrm{y}$

$\sum X^{2}=$ Total jumlah dari variabel $\mathrm{x}$ kuadrat

$\sum Y^{2}=$ Total jumlah dari variabel y kuadrat

Untuk mengetahui seberapa besar pengaruh kandungan nitrat dan fosfat disedimen terhadap kerapatan jenis mangrove dilakukan analisis regresi yang dapat dilihat sebagai berikut :

$\bar{\Upsilon}=a+b X$

dimana:

$a=\frac{\left(\sum y\right) \sum x^{2}-\left(\sum x\right)\left(\sum x y\right)}{n \sum x^{2}-\left(\sum x\right)^{2}}$ $b=\frac{n \sum x y-\left(\sum x\right)\left(\sum y\right)}{n \sum x^{2}-\left(\sum x\right)^{2}}$

Keterangan :

$\bar{Y} \quad=$ Peubah tak bebas

$X \quad=$ Peubah bebas

a = Perpotongan dengan sumbu y bila $\mathrm{x}=0$

$\mathrm{b}=$ Nilai perubahan variabel $\mathrm{y}$ bila variabel $\mathrm{x}$ berubah satu satuan

Dalam menginterpretasi model regresi digunakan koefisien determinasi yang dapat dilihat sebagai berikut :

$R^{2}=\frac{a \sum y+b \sum x y-n(\bar{Y})^{2}}{\sum y^{2}-n(\bar{Y})^{2}}$

\section{Hasil dan Pembahasan}

\subsection{Nitrat}

Hasil pengukuran kandungan nitrat pada 12 titik pengambilan sampel sedimen mangrove di kawasan Mertasari dan TPA Suwung yaitu berkisar 0,08 - 79,034 mg/L. Nilai kandungan nitrat dilokasi yang berbeda dapat dilihat pada Gambar 2. Sedimen merupakan tempat penyimpan fosfor yang baik. Tanaman dan hewan yang mati akan diuraikan oleh bakteri pengurai yang selanjutnya akan mengendap di dasar perairan (Arizuna et al, 2014). Nitrat pada sedimen merupakan nutrien nutrien yang dibutuhkan mangrove dalam pertumbuhannya. Titik 6 TPA Suwung memiliki kandungan nitrat lebih tinggi dibandingkan dengan titik 4,5,1, dan titik 3, hal ini diduga karena letak titik 6 merupakan tempat saluran buangan limbah yang menuju kearah pantai berupa air lindi. Menurut Hadiwidodo et al (2012) menjelaskan bahwa air lindi merupakan air yang terbentuk dalam timbunan sampah yang melarutkan senyawa yang ada sehingga memiliki kandungan pencemar khususnya zat organik yang sangat tinggi. Air lindi sangat berpotensi menyebabkan pencemaran air, baik air tanah maupun permukaan sehingga perlu ditangani dengan baik.

Kandungan nitrat tertinggi di kawasan mertasari yaitu di titik 3 dikarenakan letak pengamatan merupakan tempat masuknya aliran sungai ke hutan mangrove dikawasan metasari. Menurut Budiasih (2015) menyatakan bahwa, distribusi horisontal kadar nitrat semakin tinggi menuju ke arah pantai dan kadar tertinggi biasanya ditemukan di perairan muara, diakibatkan adanya sumber nitrat dari daratan berupa buangan limbah yang mengandung nitrat. 


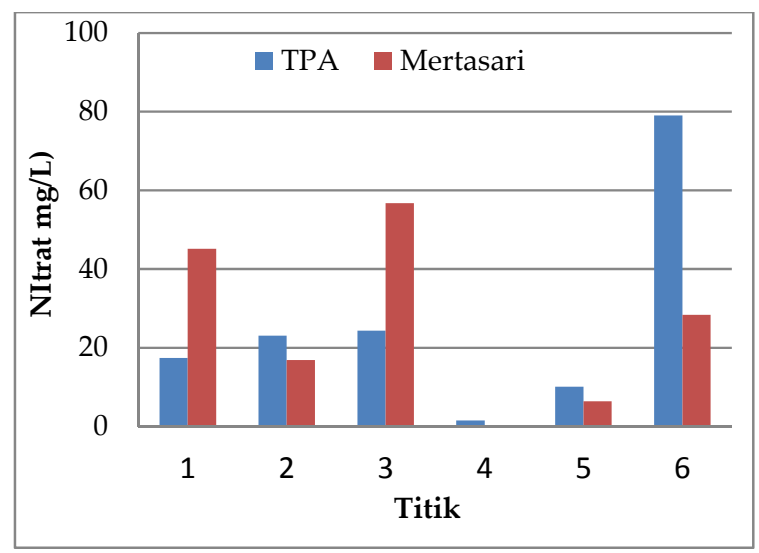

Gambar 2. Grafik hasil pengukuran nitrat sedimen di TPA Suwung dan Kawasan Mertasari Denpasar

Kandungan nitrat terendah diperoleh pada titik 4 di Kawasan Mertasari dan TPA Suwung Denpasar. Rendahnya kandungan nitrat di titik 4 dikarenakan adanya substrat yang sedikit berpasir, dimana ini juga ditemukan pada penelitian Yanti et al (2014) yaitu substrat yang berpasir didalam sedimen mangrove dengan menjelaskan bahwa substrat berupa pasir akan lebih mudah melepaskan kandungan unsur hara didalamnya dibandingkan dengan substrat yang lebih rapat porinya.

Diperoleh hasil rata - rata kandungan nitrat di Kawasan Mertasari dan Aliran Sungai TPA Suwung yaitu 25,579 mg/L dan 25,904 mg/L. Dari hasil yang diperoleh Aliran Sungai TPA Suwung memilki nilai kandungan nitrat yang tinggi dibandingkan dengan Kawasan Mertasari, dikarenakan tempat pengambilan data merupakan sumber limbah dari permukaan dimana konsentrasi nitrat yang tinggi pada air permukaan menyebabkan eutrofikasi (pengkayaan air dengan hara yang berlebihan).

\subsection{Fosfat}

Dari pengukuran laboratorium yang telah dilakukan diperoleh hasil fosfat sedimen di Kawasan Mertasari dan aliran Sungai TPA Suwung yaitu berkisar 0,04-20,292 mg/L. Nilai kandungan fosfat dilokasi yang berbeda dapat dilihat pada Gambar 3. Kandungan fosfat pada lokasi penelitian di titik 1 TPA Suwung tergolong tinggi. Lokasi penelitian merupakan area pusat pembuangan sampah didaerah Denpasar, sehingga limbah cair masuk ke dalam sedimen mangrove. Untuk Kawasan Mertasari kandungan fosfat sedimen mangrove tergolong tinggi di titik 2 karena adanya asupan zat hara dari sungai yang masuk ke wilayah mangrove. Hasil kandungan fosfat yang cukup tinggi diperoleh pada penelitian Chrisyariati et al (2014) berkisar 5,26 mg/L - 10,65 $\mathrm{mg} / \mathrm{L}$ dengan lokasi yang berbeda. Keberadaan fosfat yang tinggi disebabkan oleh masuknya limbah domestik, pertanian, industri, dan perikanan yang mengandung fosfat.

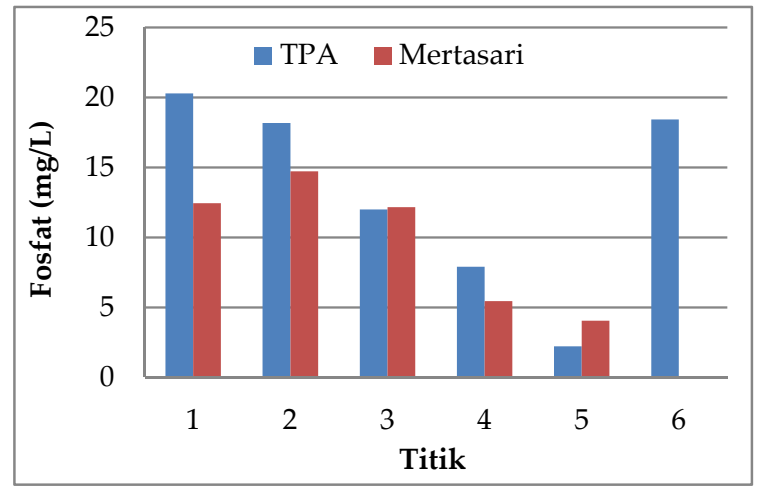

Gambar 3. Grafik hasil pengukuran fosfat sedimen mangrove di TPA Suwung dan Kawasan Mertasari Denpasar

Kandungan fosfat terendah di Kawasan Mertasari dan TPA Suwung terletak di titik 6 dan 5 . Rendahnya kandungan fosfat dikarenakan sedikitnya masukan sampah yang berada di kawasan mangrove alami. Sesuai dengan hasil yang didapatkan oleh Chrisyariati (2014) bahwa kandungan fosfat yang sedikit dapat disebabkan karena sampah yang ada disekitar sedikit, disebabkan konsentrasi fosfat yang besar dapat terjadi karena suatu proses ekskresi oleh ikan dalam bentuk feces, sehingga fosfor dalam bentuk ini dapat terakumlasi di sedimen.

Diperoleh hasil pengukuran fosfat di Aliran Sungai TPA Suwung dan Kawasan Mertasri dengan rata - rata yaitu $13,169 \mathrm{mg} / \mathrm{L}$ dan 8,143 $\mathrm{mg} / \mathrm{L}$. Dimana nilai rata - rata tertinggi fosfat diperoleh pada lokasi Aliran Sungai TPA Suwung, dikarenakan sumber fosfat yaitu sumbangan dari daratan melalui sungai.

\subsection{Kerapatan Jenis dan Kerapatan Relatif Jenis}

Hasil penelitian yang dilakukan pada 6 titik di TPA Suwung Denpasar ditemukan 5 jenis mangrove yang terdiri dari Rhizopora Mucronata, Rhizopora Apiculata, Avicinea Alba, Soneratia Alba, dan Rhizopora Stilosa. TPA Suwung Denpasar 
Tabel 3

Data kerapatan jenis dan kerapatan relatif jenis mangrove di TPA Suwung Denpasar

\begin{tabular}{|c|c|c|c|c|c|c|c|}
\hline \multirow{2}{*}{ Titik } & \multirow{2}{*}{ Jenis Mangrove } & \multicolumn{2}{|c|}{ Pohon } & \multicolumn{2}{|c|}{ Anakan } & \multicolumn{2}{|c|}{ Semai } \\
\hline & & $\operatorname{Di}\left(\mathrm{Ind} / \mathrm{m}^{2}\right)$ & Rdi (\%) & Di (Ind/m²) & Rdi (\%) & $\operatorname{Di}\left(\operatorname{Ind} / \mathrm{m}^{2}\right)$ & Rdi (\%) \\
\hline \multirow[t]{4}{*}{1} & Rhizopora Mucronata & 0,05 & 71,43 & 0,1 & 100 & 0,32 & 100 \\
\hline & Rhizopora Apiculata & 0,01 & 14,28 & - & - & - & - \\
\hline & Avicinea Alba & 0,01 & 14,28 & - & - & - & - \\
\hline & Total & 0,07 & 99,99 & 0,1 & 100 & 0,32 & 100 \\
\hline \multirow[t]{4}{*}{2} & Rhizopora Mucronata & 0,04 & 57,14 & 0,03 & 0,02 & 100 & 100 \\
\hline & Avicinea Alba & 0,01 & 14,28 & - & - & - & - \\
\hline & Soneratia Alba & 0,02 & 28,57 & - & - & - & - \\
\hline & Total & 0,07 & 99,99 & 0,03 & 100 & 0,02 & 100 \\
\hline \multirow[t]{5}{*}{3} & Rhizopora Mucronata & 0,03 & 37,5 & 0,1 & 100 & 0,32 & 100 \\
\hline & Rhizopora Apiculata & 0,02 & 25 & - & - & - & - \\
\hline & Rhizopora Stilosa & 0,02 & 25 & - & - & - & - \\
\hline & Avicinea Alba & 0,01 & 12,5 & - & - & - & - \\
\hline & Total & 0,08 & 100 & 0,1 & 100 & 0,32 & 100 \\
\hline \multirow[t]{3}{*}{4} & Rhizopora Apiculata & 0,07 & 70 & 0,02 & 100 & 0,01 & 100 \\
\hline & Soneratia Alba & 0,03 & 30 & - & - & - & - \\
\hline & Total & 0,1 & 100 & 0,02 & 100 & 0,01 & 100 \\
\hline \multirow[t]{3}{*}{5} & Soneratia Alba & 0,03 & 50 & - & - & - & - \\
\hline & Rhizopora Apiculata & 0,03 & 50 & 0,02 & 100 & 0,01 & 100 \\
\hline & Total & 0,06 & 100 & 0,02 & 100 & 0,01 & 100 \\
\hline 6 & Soneratia Alba & 0,01 & 100 & - & - & - & - \\
\hline
\end{tabular}

merupakan pusat pembuangan sampah untuk wilayah Denpasar dari sampah organik dan anorganik. Lingkungan mangrove TPA Suwung terdapat aliran sungai berhadapan langsung dengan perairan laut yang memiliki tipe substrat berlumpur. Tumbuhan mangrove sebagaimana tumbuhan lainnya mengkonversi cahaya matahari dan zat hara (nutrient) menjadi jaringan tumbuhan melalui proses fotosintesis (Lekatompessy and Alfredo, 2010). Dari hasil pengukuran nilai kerapatan jenis disetiap titik berdasarkan tingkat pohon yaitu berkisar $0,01 \mathrm{ind} / \mathrm{m}^{2}-0,07 \mathrm{ind} / \mathrm{m}^{2}$, tingkat anak berkisar $0,02 \mathrm{ind} / \mathrm{m}^{2}-0,1 \mathrm{ind} / \mathrm{m}^{2}$ dan tingkat semai berkisar $0,01 \mathrm{ind} / \mathrm{m}^{2}-0,032 \mathrm{ind} / \mathrm{m}^{2}$. Setiap titik pengukuran diperoleh hasil kerapatan relatif di tingkat pohon yaitu berkisar antara 12,5\% - 100\%, tingkat anakan dan semai diperoleh 100\%.

Hampir semua titik ditemukan jenis mangrove Rhizopora Apiculata dan Rhizopora Mucronata. Berdasarkan tingkat pohon disetiap titik jenis Rhizopora Apiculata memilki nilai kerapatan tertinggi dibandingkan dengan jenis mangrove lainnya yaitu $0,07 \mathrm{ind} / \mathrm{m}^{2}$. Jenis ini dapat tumbuh dikarenakan adanya masukan air tawar secara terus menerus. Masukan air tawar yang secara terus - menerus di lokasi penelitian ini berasal dari aliran sungai yang berdampingan dengan TPA Suwung Denpasar. Hasil penelitian yang dilakukan di TPA Suwung ditemukan tingkat anakan jenis Rhizopora Mucronata memiliki nilai kerapatan tertinggi dari jenis mangrove lainnya pada titik 2 yaitu $0,03 \mathrm{ind} / \mathrm{m}^{2}$. Dengan jenis dan titik yang sama diperoleh nilai kerapatan tertinggi di tingkat semai yaitu $100 \mathrm{ind} / \mathrm{m}^{2}$.

Pada titik 6 tidak ditemukannya mangrove tingkat anakan dan semai. Dikarenakan kondisi titik 6 merupakan tempat mengalirnya limbah cair dari TPA Sampah kemudian menyerap ke pori sedimen yang menuju ke arah selatan (laut) sehingga nitrat sedimen dititik 6 lebih tinggi dibandingkan nitrat di titik yang lainnya. Sesuai dengan hasil dari penelitian Arbain (2008) bahwa status kualitas air tanah dangkal yang berada pada jarak 1 - 375 meter dari TPA Sampah Suwung sudah tergolong dalam tingkatan tercemar berat. Hasil pengukuran kerapatan jenis dan kerapatan relatif dapat dilihat pada Tabel 3.

Kawasan Mertasari Denpasar merupakan kawasan hutan mangrove alam yang bersubstrat lumpur berpasir. Pengambilan data kerapatan jenis dan relatif mangrove dilakukan pada substrat berlumpur dan berpasir ke arah laut. Penelitian dilkukan 6 titik ditemukan 5 jenis mangrove yang terdiri dari Rhizopora Mucronata, Rhizopora Apiculata, Soneratia Alba, Bruguiera Cylindrica, dan Rhizopora Stilosa yang dapat dilihat pada Tabel 4 . 
Tabel 4

Data kerapatan jenis dan kerapatan relatif jenis mangrove di Kawasan Mertasari Denpasar

\begin{tabular}{|c|c|c|c|c|c|c|c|}
\hline \multirow{2}{*}{ Titik } & \multirow{2}{*}{ Jenis Mangrove } & \multicolumn{2}{|c|}{ Pohon } & \multicolumn{2}{|c|}{ Anakan } & \multicolumn{2}{|c|}{ Semai } \\
\hline & & Di (Ind/m²) & Rdi (\%) & $\operatorname{Di}\left(\mathrm{Ind} / \mathrm{m}^{2}\right)$ & Rdi (\%) & $\operatorname{Di}\left(\operatorname{Ind} / \mathrm{m}^{2}\right)$ & Rdi (\%) \\
\hline \multirow{3}{*}{1} & Rhizopora Mucronata & 0,01 & 8,34 & 0,08 & 100 & 0,24 & 100 \\
\hline & Rhizopora Apiculata & 0,06 & 50 & - & - & - & - \\
\hline & Soneratia Alba & 0,05 & 41,67 & - & - & - & - \\
\hline \multirow{5}{*}{2} & Total & 0,12 & 100,01 & 0,08 & 100 & 0,24 & 100 \\
\hline & Rhizopora Mucronata & 0,04 & 27,28 & 0,06 & 216,66 & 0,13 & 100 \\
\hline & Bruguiera Cylindrica & 0,04 & 36,37 & - & - & - & - \\
\hline & Soneratia Alba & 0,04 & 36,37 & - & - & - & - \\
\hline & Total & 0,12 & 100,02 & 0,06 & 216,66 & 0,13 & 100 \\
\hline \multirow{6}{*}{3} & Rhizopora Mucronata & 0,04 & 44,45 & 0,01 & 14,285 & - & - \\
\hline & Soneratia Alba & 0,05 & 55,54 & - & - & - & - \\
\hline & Bruguiera Cylindrica & - & - & 0,03 & 42,857 & - & - \\
\hline & Rhizopora Apiculata & - & - & 0,01 & 14,285 & - & - \\
\hline & Rhizopora Stilosa & - & - & 0,02 & 28,571 & - & - \\
\hline & Rhizopora Brugurea & - & - & - & - & 0,01 & 100 \\
\hline \multirow{6}{*}{4} & Total & 0,09 & 99,99 & 0,07 & 99,998 & 0,01 & 100 \\
\hline & Rhizopora Apiculata & 0,02 & 9,52 & - & - & - & - \\
\hline & Soneratia Alba & 0,07 & 33,34 & - & - & - & - \\
\hline & Rhizopora Stilosa & 0,01 & 4,76 & - & - & - & - \\
\hline & Bruguiera Cylindrica & 0,11 & 52,38 & 0,1 & 100 & 0,18 & 100 \\
\hline & Total & 0,21 & 100 & 0,1 & 100 & 0,18 & 100 \\
\hline \multirow{3}{*}{5} & Soneratia Alba & 0,07 & 46,67 & - & - & - & - \\
\hline & Bruguiera Cylindrica & 0,07 & 46,67 & 0,07 & 100 & 0,2 & 100 \\
\hline & Rhizopora Mucronata & 0,01 & 6,67 & - & - & - & - \\
\hline \multirow{6}{*}{6} & Total & 0,15 & 100,01 & 0,07 & 100 & 0,2 & 100 \\
\hline & Rhizopora Mucronata & 0,01 & 12,5 & - & - & - & - \\
\hline & Bruguiera Cylindrica & 0,03 & 37,5 & 0,07 & 58,34 & 0,08 & 53,34 \\
\hline & Soneratia Alba & 0,04 & 50 & - & - & - & - \\
\hline & Rhizopora Stilosa & - & - & 0,05 & 0,6 & 0,7 & 46,67 \\
\hline & Total & 0,08 & 100 & 0,12 & 58,94 & 0,78 & 100,01 \\
\hline
\end{tabular}

Hasil pengukuran kerapatan jenis mangrove pada Tabel 4 disetiap titik berdasarkan tingkat pohon yaitu berkisar 0,08 ind $/ \mathrm{m}^{2}-0,21 \mathrm{ind} / \mathrm{m}^{2}$, tingkat anakan berkisar antara 0,06 ind $/ \mathrm{m}^{2}-0,12$ ind $/ \mathrm{m}^{2}$, dan tingkat semai berkisar $0,01 \mathrm{ind} / \mathrm{m}^{2}-$ $0,78 \mathrm{ind} / \mathrm{m}^{2}$. Diperoleh hasil pengukuran kerapatan relatif mangrove di setiap titik yang berdasarkan tingkat pohon yaitu berkisar 4,76 \% - 55, 54\%, tingkat anakan berkisar antara 0,6 \% - 216,66 \% , dan tingkat semai berkisar 46,67 \% - $100 \%$.

Kerapatan jenis mangrove merupakan parameter untuk menduga kepadatan jenis mangrove pada suatu komunitas. Kerapatan jenis pada suatu area dapat memberikan gambaran ketersediaan dan potensi tumbuhan mangrove.Kerapatan jenis mangrove merupakan parameter untuk menduga kepadatan jenis Setiap titik pengukuran kerapatan jenis dan relatif mangrove di Kawasan Mertasari berdasarkan tingkat pohon, anakan, semai yang banyak ditemukan jenis Bruguiera Cylindrica, Soneratia Alba, dan Rhizopora Mucronata. Pada tingkat pohon jenis Bruguiera Cylindrica memilki nilai kerapatan jenis lebih tinggi dibandingkan dengan jenis mangrove lainnya. Tingginya nilai kerapatan jenis mangrove Bruguiera Cylindrica diduga tempat pengukuran kerapatan jenis mangrove memilki substrat berlumpur atau dengan substrat liat dan sedikit ada substrat berpasir. Untuk tingkat anakan dan semai jenis mangrove yang sering ditemukan pada saat pengukuran adalah jenis mangrove Rhizopora Mucronata.Jenis ini merupakan jenis yang memiliki nilai kerapatan yang lebih tinggi dibandingkan jenis mangrove lainya dengan substrat berlumpur. Genus Rhizophora terutama R. Mucronata umumnya tumbuh dengan baik pada daerah berlumpur datar.

Dari hasil perhitungan kerapatan mangrove di Aliran Sungai TPA Suwung dan Kawasan 
Mertasari di setiap titiknya lebih banyak ditemukan jenis Rhizopora $s p$, diduga karena jenis ini merupakan jenis tanaman mangrove yang toleran terhadap kadar garam yang tinggi, dan kondisi tanah yang tidak stabil. Hasil yang sama juga diperoleh Wiyanto (2015) yang hampir disemua stasiun pengambilan data di Teluk Benoa ditemukan jenis Rhizopora sp. Dalam penelitiannya menjelaskan bahwa jenis Rhizopora $s p$ merupakan termasuk dalam tumbuhan mangrove sejati. Mangrove sejati merupakan mangrove yang hanya dapat tumbuh di ligkungan pasang surut atau daerah yang tergenang.

3.4 Keterkaitan Kerapatan Mangrove dengan Kkandungan Nitrat dan Fosfat Sedimen Mangrove

Kerapatan jenis pada suatu area dapat memberikan gambaran ketersediaan dan potensi tambahan mangrove. Untuk melihat keterkaitan mangrove dengan kandunagan nitrat dan fosfat di sedimen digunakan analisis regresi liner sederhana menggunakan Microsoft Office Excel. Variabel bebas diberi notasi $X$ yang merupakan kandungan nitrat dan fosfat sedimen dan variabel terikat diberi notasi $\mathrm{Y}$ adalah kerapatan jenis mangrove. Adapun penjelasan dari kerapatan mangrove dengan kandungan nitrat dan fosfat sedimen sebagai berikut:

\subsubsection{Keterkaitan Kandungan Nitrat Sedimen Dengan Kerapatan Mangrove}

Diperoleh hasil perhitungan regresi linier menghasilkan $y=-0,002 x+0,288$ dengan koefisien determinasi $\mathrm{R}^{2}=0,101$ atau sebesar 10,1 \% yang artinya tidak adanya keterkaitan antara kandungan nitrat sedimen dengan kerapatan mangrove di TPA Suwung. Hal tersebut diduga karena tempat pengambilan sampel merupakan daerah yang sudah tercemar dan sedikit ditumbuhi mangrove alami. Selain itu aliran sungai yang menuju kearah laut dengan adanya masukkan limbah cair yang berupa air lindi kemudian menyerap kepori sedimen didaerah tersebut menyebabkan mangrove alami tidak dapat tumbuh secara maksimal(Yanti et al (2014)).

Dalam perhitungan regresi linier dengan kandungan nitrat sedimen di Kawasan Mertasari menghasilkan $\mathrm{y}=-0,002 \mathrm{x}+0,537$, koefisien determinasi $\mathrm{R}^{2}$ yang diperoleh adalah 0,047 yang artinya keterkaitan kerapatan jenis mangrove dengan nitrat sedimen di Kawasan Mertasari sebesar 4,7\%. Dengan koefisien korelasi yang diperoleh dari Kawasan Mertasari adalah - 0,218 dan Aliran Sungai TPA Suwung yaitu - 0,318 yang artinya kandungan nitrat sedimen dengan kerapatan mangrove bernilai negatif dan tidak adanya keterkaitan antara kandungan nitrat sedimen dengan kerapatan mangrove yang dapat dilihat pada pada Gambar 4 dan 5.

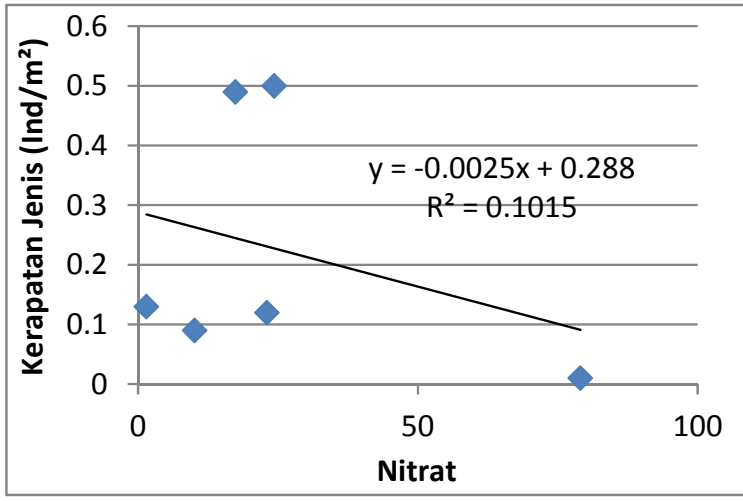

Gambar 4. Keterkaitan kandungan nitrat sedimen dengan kerapatan mangrove di Aliran Sungai TPA Suwung

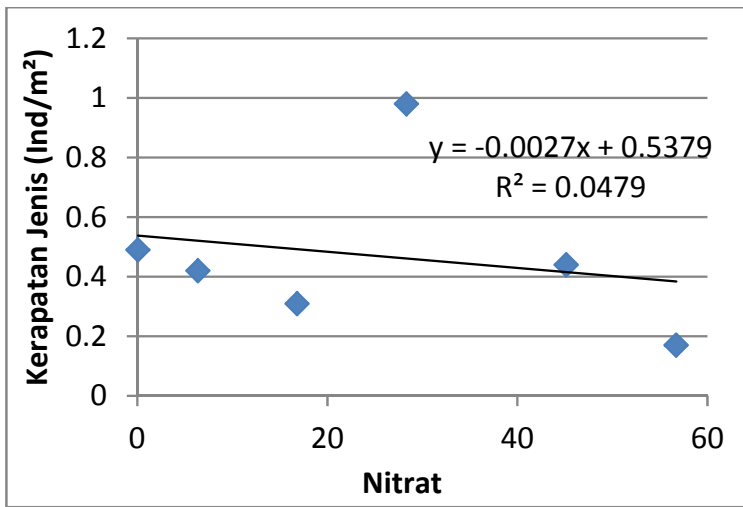

Gambar 5. Keterkaitan kandugan nitrat sedimen dengan kerapatan mangrove Kawasan Mertasari

Hasil korelasi yang negatif antara kandungan nitrat sedimen dengan kerapatan mangrove diduga karena saat pengambilan sampel sedimen hanya pada kedalaman $30 \mathrm{~cm}$ (permukaan), diduga kandungan nitrat hanya ada dalam permukaan, karena akar dalam nutrien yang brada dalam tanah di kedalaman $60 \mathrm{~cm}$. Secara umum, pengambilan sampel sedimen untuk tanaman tahunan yaitu pada kedalaman $60 \mathrm{~cm}$ (Hartoko et al , 2013). Menurut Handayanto dan hairiah 2009 nitrat yang tercuci atau terbawa oleh arus pada 
akhirnya akan memasuki air permukaan yang menyebabkan pencemaran lingkungan.

Hasil koefisien determinasi yang diperoleh antara kerapatan jenis mangrove dengan nitrat sedimen di TPA Suwung dan Kawasan Mertasari yaitu sebesar 10,1 \% dan 4,7\%. Artinya besar pengaruh dari hasil koefisien determinasi yaitu hanya sedikit yang berpengaruh antara kandungan nitrat sedimen dengan kerapatan mangrove yang merupakan mangrove adalah tanaman tahunan. Selain itu, saat pengambilan sampel dikedalaman $30 \mathrm{~cm}$ (permukaan), diduga nitrat yang ada dalam sedimen permukaan mudah terbawa oleh percampuran air tawar dengan air laut yang menyebabkan sedikitnya penyerapan nitrat dalam tanah - tanaman. Hal ini diduga memiliki karakteristik yang sama dengan yang sebelumnya.

3.4.2 Keterkaitan kerapatan mangrove dengan kandungan fosfat disedimen

Dalam perhitungan regresi linier sederhana dengan kerapatan jenis mangrove menghasilkan y $=0,007 x+0,125$ dengan koefisien determinasi $R^{2}$ yaitu 0,061 atau sebesar 6,1 \% yang artinya kecilnya (sedikit) pengaruh dari kandungan fosfat sedimen dengan kerapatan jenis mangrove di TPA Suwung (Gambar 6). Koefisien korelasi (r) yang diperoleh adalah 0,247 artinya antara kerapatan jenis mangrove dengan fosfat sedimen berkorelasi positif tetapi sangat lemah. Diduga mangrove alami yang tumbuh dilingkungan TPA Suwung terbilang sedikit menyebabkan kecilnya hasil kerapatan jenis mangrove dan tumbuhan mangrove ini merupakan tumbuhan tahunan bukan musiman. Kecilnya kerapatan jenis mangrove mengakibatkan fosfat yang terkandung dalam sedimen mudah terbawa oleh pasang surut. Pernyataan ini sependapat dengan Andriawan (2016) menjelaskan bahwa kecilnya kerapatan mangrove mengakibatkan nitrat dan fosfat yang terkandung dalam sedimen akan sangat mudah terbawa oleh arus pasang surut.

Di Kawasan Mertasari diperoleh hasil perhitungan regresi linier sederhana yaitu $\mathrm{y}=$ $0,038 x+0,777$ dengan koefisien determinasinya $\mathrm{R}^{2}$ adalah 0,637atau sebesar $63,7 \%$ artinya besar pengaruh dari kandungan fosfat sedimen dengan kerapatan mangrove yaitu bepengaruh sedang. Koefisien korelasi ( $\mathrm{r}$ ) yang diperoleh adalah $-0,798$ artinya antara kerapatan jenis mangrove dengan fosfat sedimen berkorelasi negatif tetapi sangat lemah (Gambar 7). Hal ini diduga memilki karakteristik yang sama dengan korelasi di Aliran Sungai TPA Suwung.

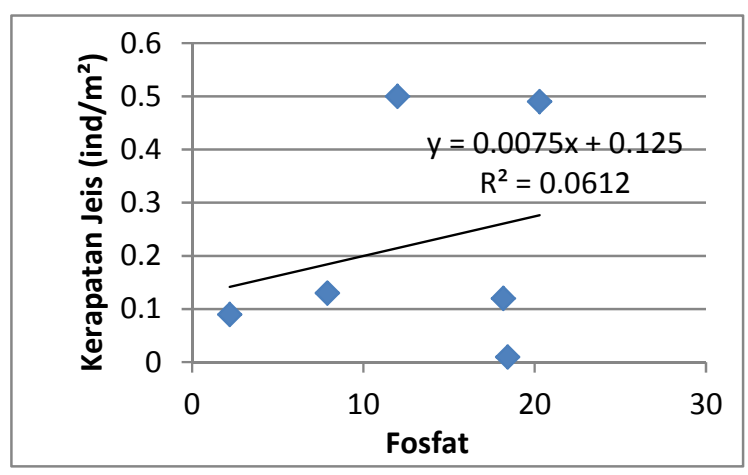

Gambar 6. Keterkaitan kandungan fosfat sedimen dengan kerapatan jenis di Aliran TPA Suwung

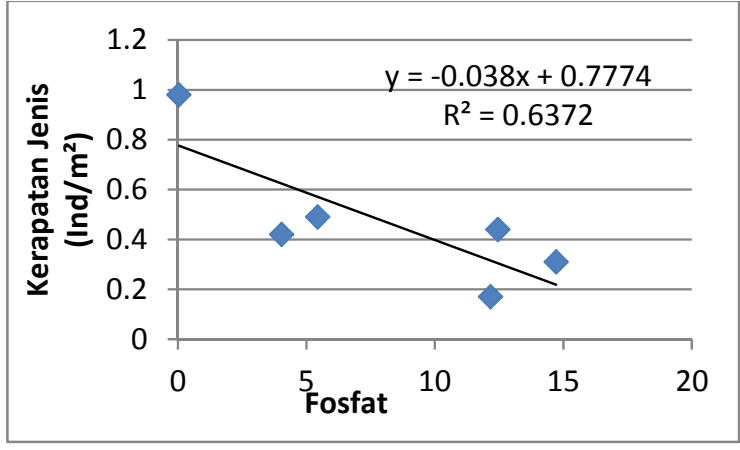

Gambar 7. Keterkaitan kandungan fosfat sedimen dengan kerapatan jenis mangrove di Kawasan Mertasari

Dari dua tempat yang berbeda diperoleh hasil koefisien determinasi yaitu 6,1 \% dan 63,7\%, artinya besar pengaruh dari kandungan fosfat sedimen dengan kerapatan mangrove yaitu pengaruhnya kecil(sedikit). Dikarenakan pada saat pengambilan sampel sedimen di kawasan mangrove alami hanya pada kedalaman $30 \mathrm{~cm}$ (permukaan). Secara umum, pengambilan sampel sedimen untuk tanaman tahunan yaitu pada kedalaman $60 \mathrm{~cm}$ (Hartoko et al , 2013). Selain hal itu, diduga pada saat pengukuran mangrove seta pengambilan sampel sedimen daerah yang tercemar dan terdapat aliran sungai menuju ke arah laut. Menurut Yanti et al, 2014 aliran sungai yang menuju kearah laut dengan adanya masukkan limbah cair yang berupa air lindi kemudian menyerap kepori sedimen didaerah tersebut menyebabkan mangrove alami tidak dapat tumbuh secara maksimal. 


\section{Simpulan}

Berdasarkan hasil yang diperoleh dari penelitian ini dapat disimpulkan bahwa pada 12 titik pengambilan sampel sedimen mangrove di Kawasan Mertasari dan Aliran Sungai TPA Suwung diperoleh hasil pengukuran nitrat yaitu berkisar $0,08 \mathrm{mg} / \mathrm{L} \quad$ - 79,034 mg/L. Hasil pengukuran fosfat sedimen mangrove yaitu berkisar antara $0,04 \mathrm{mg} / \mathrm{L}-20,292 \mathrm{mg} / \mathrm{L}$ hal ini diduga karena adanya sumbangan dari daratan melalui sungai keperairan tersebut.

Kerapatan jenis mangrove di Aliran Sungai TPA Suwung dengan Kawasan Mertasari di setiap titik pada tingkat pohon berkisar $0,01 \mathrm{ind} / \mathrm{m}^{2}-0$, $21 \mathrm{ind} / \mathrm{m}^{2}$, tingkat anakan $0,02 \mathrm{ind} / \mathrm{m}^{2}-0,12$ ind $/ \mathrm{m}^{2}$, dan tingkat semai $0,01 \mathrm{ind} / \mathrm{m}^{2}-0,78$ ind $/ \mathrm{m}^{2}$. Hal ini diduga karena pada saat dilakukan pengukuran hanya mengukur mangrove alami. Sedangkan daerah lokasi penelitian terdapat banyaknya mangrove rehabilitasi.

Besar keterkaitannya hanya sedikit yang berpengaruh terhadap kandungan nitrat dan fosfat sedimen dengan kerapatan mangrove di dua lokasi yang berbeda. Dikarenakan pada saat pengambilan sampel sedimen dikedalaman $30 \mathrm{~cm}$ (permukaan) dan dilakukannya pengambil sampel sedimen ini hanya 1 kali pengulangan.

\section{Saran}

Saran yang dapat diberikan dalam penelitian ini yaitu perlu adanya penelitian lebih lanjut untuk melihat keterkaitan kerapatan jenis mangrove dengan parameter lingkungan lainnya seperti; salinitas tanah, $\mathrm{pH}$ tanah, substrat tanah yang menghasilkan korelasi negatif. Serta penelitian kandungan nitrat dan fosfat pada kedalaman 60 $\mathrm{cm}$ di sedimen keterkaitannya dengan kerapatan mangrove alami maupun rehabilitasi.

\section{Daftar Pustaka}

Arbain, A., Mardana, N. K., \& Sudana, I. B. (2008). Pengaruh Air Lindi Tempat Pembuangan Akhir Sampah Suwung Terhadap Kualitas Air Tanah Dangkal Di Sekitarnya Di Kelurahan Pedungan Kota Denpasar. Ecotrophic: Journal of Environmental Science, 3(2), 55-60.

Arizuna, M., Suprapto, D., \& Muskanonfola, M. R. (2014). Kandungan Nitrat Fosfat Dalam Air Pori Sedimen Di Sungai Dan Muara Sungai Wedung Demak. Management Of Aquatic Resources Journal, 3(1) ,7-16.
Budiasih, R., Supriharyono, S., \& Muskananfola, M. R. (2015). Analisis Kandungan Bahan Organik, Nitrat, Fosfat Pada Sedimen Di Kawasan Mangrove Jenis Rhizophora Dan Avicennia Di Desa Timbulsloko, Demak. Management Of Aquatic Resources Journal, 4(3), $66-75$

Chrisyariati, I., Hendrarto, B., Suryanti, S. (2014). Kandungan Nitrogen Total Dan Fosfat Sedimen Mangrove Pada Umur Yang Berbeda Dilingkungan Pertambakan Mangunharjo, Semarang. Management Of Aquatic Resources Journal, 3(3), 65-72

Dahuri, R., Rais, J., Ginting, S. P., \& Sitepu, M. J. (2008). Pengelolaan Sumber Daya Wilayah Pesisir dan Lautan secara Terpadu. Cetakan ke Empat. Jakarta, Indonesia: Pradnya Paramita.

Feller, I. C., Lovelock, C. E., Berger, U., McKee, K. L., Joye, S. B., \& Ball, M. C. (2010). Biocomplexity in mangrove ecosystems. Annual Review of Marine Science, 2, 395-417.

Hadiwidodo, M., \& Oktiawan, W., Primadani, A. R., Parasmita, B. N., \& Gunawan, I. (2012). Pengolahan Air Lindi Dengan Proses Kombinasi Biofilter Anaerob-Aerob Dan Wetland. Jurnal Presipitasi: Media Komunikasi dan Pengembangan Teknik Lingkungan, 9(2), 84-95.

Handayanto, E., \& Hairiah, K. (2007). Biologi Tanah Landasan Pengelolaan Tanah Sehat. Yogyakarta, Indonesia: Pustaka Adipura.

Indrawati, A., Hartoko, A., \& Soedarsono, P. (2013). Analisa klorofil- $\alpha$, Nitrat Dan Fosfat Pada Vegetasi Mangrove Berdasarkan Data Lapangan Dan Data Satelit Geoeye Di Pulau Parang, Kepulauan Karimunjawa. Management of Aquatic Resources Journal, 2(2), 28-37

Lekatompessy, S. T. A., \& Tutuhatunewa, A. (2010). Kajian kontruksi model peredam gelombang dengan menggunakan mangrove di Pesisir Lateri-Kota Ambon. Jurnal Arika, 4(1), 51-60.

Lewis, M., Pryor, R., \& Wilking, L. (2011). Fate and effects of anthropogenic chemicals in mangrove ecosystems: a review. Environmental pollution, 159(10), 2328-2346.

Mahasani, I. G. A. I., Widagti, N., \& Karang, I. W. G. A. (2015). Estimasi persentase karbon organik di hutan mangrove bekas tambak, Perancak, Jembrana, Bali. Journal of Marine and Aquatic Sciences, 1(1), 14-18.

Polidoro, B. A., Carpenter, K. E., Collins, L., Duke, N. C., Ellison, A. M., Ellison, J. C., Farnsworth, E. J., Fernando E. S., Kathiresan ,K., Koedam, N. E., Livingstone, S. R., Miyagi, T., Moore ,G. E., Nam, V. N., Ong, J. E., Primavera, J. H., Salmo III, S. G, Sanciangco, J., Sukardjo, S., Wang, Y., Hong Yong , J. W. (2010). The loss of species: mangrove extinction risk and geographic areas of global concern. PloS One, 5(4), e10095. 
Pratiwi, M. A., \& Ernawati, N. M. (2016). Analisis Kualitas Air dan Kepadatan Moluska pada Kawasan Ekosistem Mangrove, Nusa Lembongan. Journal of Marine and Aquatic Sciences, 2(2), 67-72.

Rahardja, B. S., Andriawan, S., Alamsjah, M. A., \& Pursetyo, K. T. (2016). Perbandingan Unsur Hara Nitrogen dan Fosfor Tanah Terhadap Jenis Keanekaragaman Mangrove Di Muara Sungai Gunung Anyar Surabaya dan Bancaran Bangkalan. Journal of Marine and Coastal Science, 5(1), 9-21.

Suwargana, N. (2010). Analisis Perubahan Hutan Mangrove Menggunakan Data Penginderaan Jauh di
Pantai Bahagia, Muara Gembong, Bekasi. Jurnal Penginderaan Jauh dan Pengolahan Data Citra Digital, 5, 64-74.

Yanti N. S. Bintal A. Efriyeldi. (2014) . Kontribusi Unsur Hara Berdasarkan Jenis Mangrove Di Kelurahan Pangkalan Sesai Kota Dumai. Skripsi. Riau, Indonesia: Jurusan Ilmu Kelautan. Fakultas Perikanan dan Ilmu Kelautan. Universitas Riau Pekanbaru.

Wiyanto, D. B., \& Faiqoh, E. (2015). Analisis vegetasi dan struktur komunitas Mangrove Di Teluk Benoa, Bali. Journal of Marine and Aquatic Sciences, 1(1), 1-7.

(C) 2017 by the authors; licensee Udayana University, Indonesia. This article is an open access article distributed under the terms and conditions of the Creative Commons Attribution license (http://creativecommons.org/licenses/by/3.0/). 